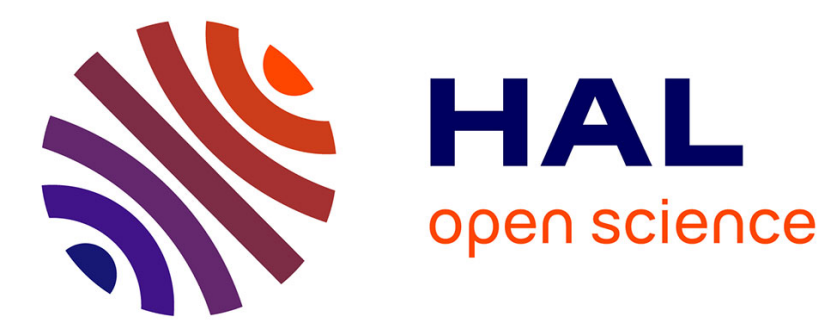

\title{
Human dental pulp stem cells: A sanctuary for relapsing Bartonella quintana
}

\author{
Hamadou Oumarou Hama, Attoumani Hamada, Gérard Aboudharam, Éric
} Ghigo, Michel Drancourt

\section{To cite this version:}

Hamadou Oumarou Hama, Attoumani Hamada, Gérard Aboudharam, Éric Ghigo, Michel Drancourt. Human dental pulp stem cells: A sanctuary for relapsing Bartonella quintana. Microbial Pathogenesis, 2021, 153, pp.104797. 10.1016/j.micpath.2021.104797 . hal-03243147

\section{HAL Id: hal-03243147 \\ https://hal-amu.archives-ouvertes.fr/hal-03243147}

Submitted on 4 Jun 2021

HAL is a multi-disciplinary open access archive for the deposit and dissemination of scientific research documents, whether they are published or not. The documents may come from teaching and research institutions in France or abroad, or from public or private research centers.
L'archive ouverte pluridisciplinaire HAL, est destinée au dépôt et à la diffusion de documents scientifiques de niveau recherche, publiés ou non, émanant des établissements d'enseignement et de recherche français ou étrangers, des laboratoires publics ou privés.

\section{(1) (1) $\$$}

Distributed under a Creative Commons Attribution - NonCommercial - NoDerivatives| 4.0 


\title{
Human dental pulp stem cells: A sanctuary for relapsing Bartonella quintana
}

\author{
Hamadou Oumarou Hama ${ }^{\text {a,b,1 }}$, Attoumani Hamada ${ }^{\text {a,b,1 }}$, Gérard Aboudharam ${ }^{\text {a,b,c }}$, \\ Éric Ghigo ${ }^{\mathrm{a}, \mathrm{d}}$, Michel Drancourt ${ }^{\mathrm{a}, \mathrm{b}, *}$ \\ a Institut Hospitalier Universitaire Méditerranée Infection, Marseille, France \\ ${ }^{\mathrm{b}}$ Aix-Marseille-Université, IRD, MEPHI, IHU Méditerranée Infection, Marseille, France \\ ${ }^{\mathrm{c}}$ UFR Odontologie, Aix-Marseille-Université, Marseille, France \\ ${ }^{\mathrm{d}}$ Aix-Marseille Univ, IRD, AP-HM, SSA, VITROME, Marseille, France
}

\section{A R T I C L E I N F O}

Keywords:

Human dental pulp stem cells

Internalization

Immunity

Bartonella quintana

\begin{abstract}
A B S T R A C T
Bartonella quintana is a facultative intracellular bacterium responsible for relapsing fever, an example of nonsterilizing immunity. The cellular sanctuary of $B$. quintana in-between febrile relapses remains unknown but repeated detection of $B$. quintana in dental pulp specimens suggested long-term half-life dental pulp stem cells (DPSCs) as candidates. As the capacity of DPSCs to internalize microscopic particles was unknown, we confirmed that DPSCs internalized B. quintana bacteria: Gimenez staining and fluorescence microscopy localized B. quintana bacteria inside DPSCs and this internalization did not affect the cellular multiplication of DPSCs during a onemonth follow-up despite the increase in the bacterial load. B. quintana-infected DPSCs did not produce Tumor Necrosis Factor- $\alpha$ whereas an important production of Monocytes Chemoattractant Protein-1 was observed. These unprecedented observations suggest the possibility that DPSCs are shelters for the long-term persistence of $B$. quintana in the host, warranting further experimental and clinical investigations.
\end{abstract}

\section{Introduction}

Bartonella quintana is a facultative intracellular gram-negative bacterium described in 1915 as the agent of trench fever, emerging during World War I in soldiers presenting with fever, headache, sore muscles, bones and joints and skin lesions on the chest and back [1,2]. Trench fever is nowadays understood as one of the clinical forms of $B$. quintana bacteremia, also responsible for life-threatening endocarditis [3-6] and bacillary angiomatosis in immunocompromised patients [7]. Further, $B$. quintana is also responsible for lymphadenopathy in the lymphatic territory of its inoculation as B. quintana is an ectoparasite-borne pathogen transmitted from person to person by the body lice $[1,8]$ and probably from cat to persons by cat fleas [9].

Trench fever is a relapsing fever and $B$. quintana has been consistently observed in circulating erythrocytes during febrile episodes [10] yet the site where B. quintana is residing in-between febrile episodes remains unknown even though the demonstration that bacillary angiomatosis results from the reactivation of quiescent $B$. quintana suggested such a role for endothelial cells as sanctuary cells [11,12]. However, neither erythrocytes nor endothelial cells have been demonstrated to host B. quintana for long, in agreement with the fact that both cell types have a limited life span time of 120 days for erythrocytes and 100 days for endothelial cells $[13,14]$.

Interestingly, B. quintana has been consistently detected in the dental pulp, a highly vascularized organ with high erythrocyte trafficking [15]. As for example, paleomicrobiology studies detected $B$. quintana with a prevalence of $2.5 \%-21.4 \%$ in the dental pulp collected in buried populations $[16,17]$. In one particular burial site of Remiremont, the prevalence of $B$. quintana in 45 dental pulp specimens collected from these $5-10$ th populations, was as high as $53.3 \%$ [18]. Also, B. quintana has been detected in the dental pulp collected from one patient who had been diagnosed with $B$. quintana bacteremia six months before tooth extraction and was free of bacteremia at the time of tooth extraction [19].

The dental pulp is composed of several cell types including dental pulp stem cells (DPSCs) which were investigated in the present study. DPSCs are mesenchymal stem cell isolated by Gronthos in 2000 and characterized by the expression of markers such as CD73, CD90 and CD105, whereas markers CD34 (hematopoietic progenitor cell antigen) and CD45 (leukocyte common antigen) are not expressed [20,21].

\footnotetext{
* Corresponding author. IHU Méditerranée Infection, 19-21 Boulevard Jean Moulin, 13385, Marseille, France.

E-mail address: michel.drancourt@univ-amu.fr (M. Drancourt).

1 These two authors equally contributed to this work.
} 
The DPSC stemness capacity correlates with a long lifespan [22,23] making them an attractive cell type to investigate hosting $B$. quintana for extended period compatible with clinical reports. In addition, DPSCs are located in the inner area of dental pulp chamber in close contact with nerve ending and could be a sentinel cells for injury and blood-borne pathogen invasion. It has been found that DPSCs present an immuno-privileged source against immune responses [24]. Indeed, DPSCs possess an immunomodulatory activity following LPS stimulation. They produce pro-inflammatory cytokines such as Interleukin (IL)-6, IL-8, Tumor Necrosis Factor (TNF)- $\alpha$ and Monocytes Chemoattractant Protein (MCP)-1 to recruit immune cell in the site of inflammation, and anti-inflammatory cytokines including IL-10 to reduce the inflammatory and maintain an homeostasis [25-27].

Based on this background, the aim of this present study was to investigate the role of DPSCs in host-pathogen interactions, using B. quintana as a paradigmal organism.

\section{Materials and methods}

\subsection{Bacterial strain}

B. quintana ATCC49793 was cultured on Columbia 5\% sheep blood agar (COS) plates (bioMérieux, Craponne, France) at $37{ }^{\circ} \mathrm{C}$ under a $5 \%$ $\mathrm{CO}_{2}$ atmosphere. The identification of $B$. quintana was confirmed by matrix-assisted laser desorption ionization/time of flight mass spectrometry (MALDI TOF MS) as previously described [28].

\subsection{DPSCs culture}

DPSCs obtained from a wisdom tooth were cultured in Dulbecco's Modified Eagle Medium F-12 (DMEM/F12, Invitrogen, Villebon-surYvette, France) supplemented with 10\% heat-inactivated foetal calf serum (FBS, qualified, EU-approved, South America origin, Gibco, Paisley, UK) at $37{ }^{\circ} \mathrm{C}$ under a $5 \% \mathrm{CO}_{2}$ atmosphere. DPSCs viability was determined by using the Trypan blue exclusion assay. This assay is distinctively differentiating non-viable from viable cells based on the analysis of the integrity of the cell membrane [29]. Briefly, $50 \mu \mathrm{L}$ of trypsinated DPSCs suspension were mixed with $50 \mu \mathrm{L}$ of a $0.4 \%$ solution of Trypan blue dye (Eurobio, Les Ulis, France) for $1 \mathrm{~min}$ at room temperature. Cells were immediately counted using a Neubauer microchamber (Brand $\mathrm{GmbH}$, Wertheim, Germany) with a light microscope using a $100 \mathrm{X}$ magnification.

\subsection{DPSCs infection}

B. quintana was collected in sterile tubes from two plates of COS and then washed twice in a row with sterile phosphate buffered saline (PBS). Infection of DPSCs $\left(6 \times 10^{6}\right)$ with $B$. quintana in cell culture medium was performed by centrifugation at $3,220 \times g$ for $1 \mathrm{~h}$. The suspension was then distributed in flasks (SARSTEDT, Nümbrecht, Germany) (i.e. $2 \mathrm{~mL}$ per flask) and incubated at $37{ }^{\circ} \mathrm{C}$ under $5 \% \mathrm{CO}_{2}$ atmosphere for a one month follow-up (12h, 24h, 48h, 72h, 1st, 2nd, 3rd and 4th week). DPSCs cultured alone and B. quintana were used as controls. After each incubation time, cells were washed thrice with sterile PBS and $200 \mu \mathrm{L}$ of cell suspension were cytospined for 5 min (Shandon Cytospin 4, Thermo Scientific, Cheshire, UK). The identification of infected DPSCs was carried by Gimenez staining.

\subsection{Fluorescent in-situ hybridization (FISH)}

At the second week of infection a FISH was performed after cytospin and fixation of the slides with $4 \%$ paraformaldehyde for $20 \mathrm{~min}$ at room temperature. FISH was carried out as previously described with some modifications [30]. Briefly, probe 16S488-AATCTTTCTCCCAGAGGG labeled with Alexa-488 fluorochrome (Eurogentec, Angers, France) targeted B. quintana 16S rRNA gene. The cellular nucleus was stained in blue using 4',6-diamidino-2-phenylindole (DAPI, Fisher Scientific, Illkirch, France). Uninfected DPSCs were used as negative controls.

\subsection{Cytokine quantification}

The supernatants in the first week of the first passage of infected DPSCs and third, fourth weeks of infection were collected to evaluate the concentration of MCP-1 and TNF- $\alpha$ by using ELISA kits according to the manufacturer's protocols (R\&D Systems, Rennes, France), the mean minimum detectable dose of human MCP- 1 was $1.7 \mathrm{pg} / \mathrm{mL}$ and $4.00 \mathrm{pg} /$ $\mathrm{mL}$ for human TNF- $\alpha$. The results were expressed in $\mathrm{pg} / \mathrm{mL}$.

\section{Results}

\subsection{Capacity of DPSCs to internalize B. quintana bacteria}

We first investigated whether DPSCs could internalize $B$. quintana bacteria. Gimenez staining allowing the staining of intracellular bacteria was our reference method. The validation of result was performed using a control of uninfected DPSCs and checking the form of $B$. quintana by Gimenez staining before infection (Fig. 1). B. quintana effectively multiplies within DPSCs as indicated by the follow-up from $12 \mathrm{~h}$ of incubation (Fig. 2). In addition, FISH was carried out in the second week of infection, confirming the presence of $B$. quintana within cells (in green) (Fig. 3). The specificity of the probe was confirmed by a negative control (Fig. 4).

\subsection{Immune response of DPSC to B. quintana infection}

We further investigated whether B. quintana internalization induced an immune pattern by DPSCs. B. quintana infection correlated with increased for MCP-1 with maximum of production in week four from 11175 to $19867.85 \mathrm{pg} / \mathrm{mL}$ (Table 1). A production of MCP-1 was observed in supernatants of uninfected DPSCs but has a low concentration compared to the infected DPSCs and remains practically stable between the third and the four weeks of incubation (Table 1). For TNF- $\alpha$, we observed an absence of production suggesting an absence of proinflammatory responses TNF- $\alpha$ in infected DPSCs (Supplementary Table S1).

\section{Discussion}

We observed that $B$. quintana was internalized by DPSCs. The infection with $B$. quintana did not affect cellular multiplication of DPSCs and despite the increase in these cells an increase in the numbers of bacteria was observed. Our observations support the hypothesis that DPSCs could act as reservoir cells for B. quintana. This hypothesis is in accordance with a study reported that intracellular $B$. quintana bacteria could be internalized into a vacuolic compartment (B. quintana-containing vacuoles) and multiply [31-33]. These observations correlate with the persistence of B. quintana in human [34]. This is opening an exciting new role for DPSCs and further exploring their function could be done by additional observations including the co-localization of B. quintana and DPSCs in dental pulp specimens. If confirmed, the role of DPSCs as sanctuary cells for other pathogens will have to be investigated.

The absence TNF- $\alpha$ production suggests that $B$. quintana inhibits or alters the production of TNF- $\alpha$, most likely to favor its replication by avoiding the induction of the microbicidal activities of the DPSCs and the recruitment of pro inflammatory cells. Despite the absence of TNF- $\alpha$ production, production of MCP-1 was observed. This production of MCP-1 has already been described previously as being produced in large quantities by DPSCs [35] and did not induce DPSCs differentiation according to the literature [36,37]. In addition, it has been described that infection with the Chikungunya virus in human peripheral blood mononuclear cells induce a large production of MCP-1. However, 

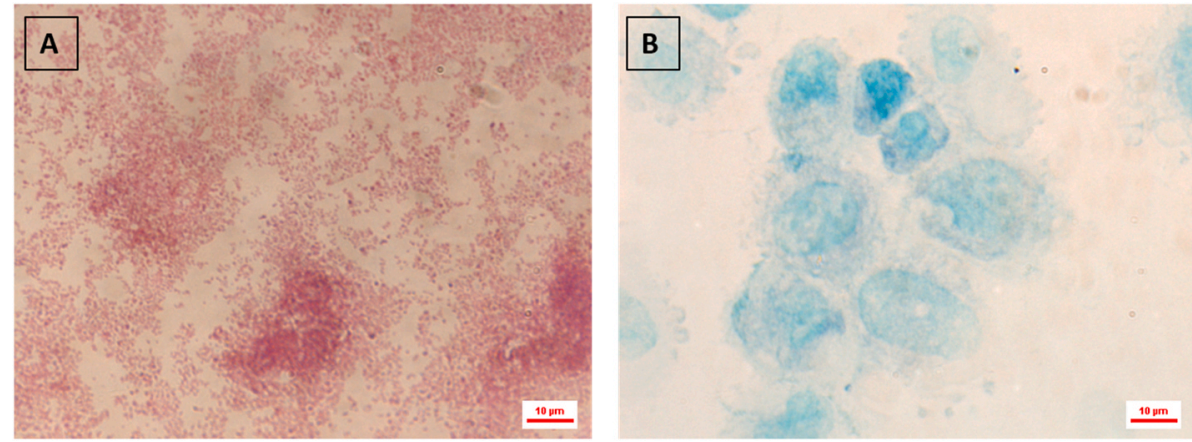

Fig. 1. Control of DPSCs and B. quintana by Gimenez staining before infection. (A) Form of B. quintana colored in red (B): uninfected DPSCs colored in green. (For interpretation of the references to color in this figure legend, the reader is referred to the Web version of this article.)

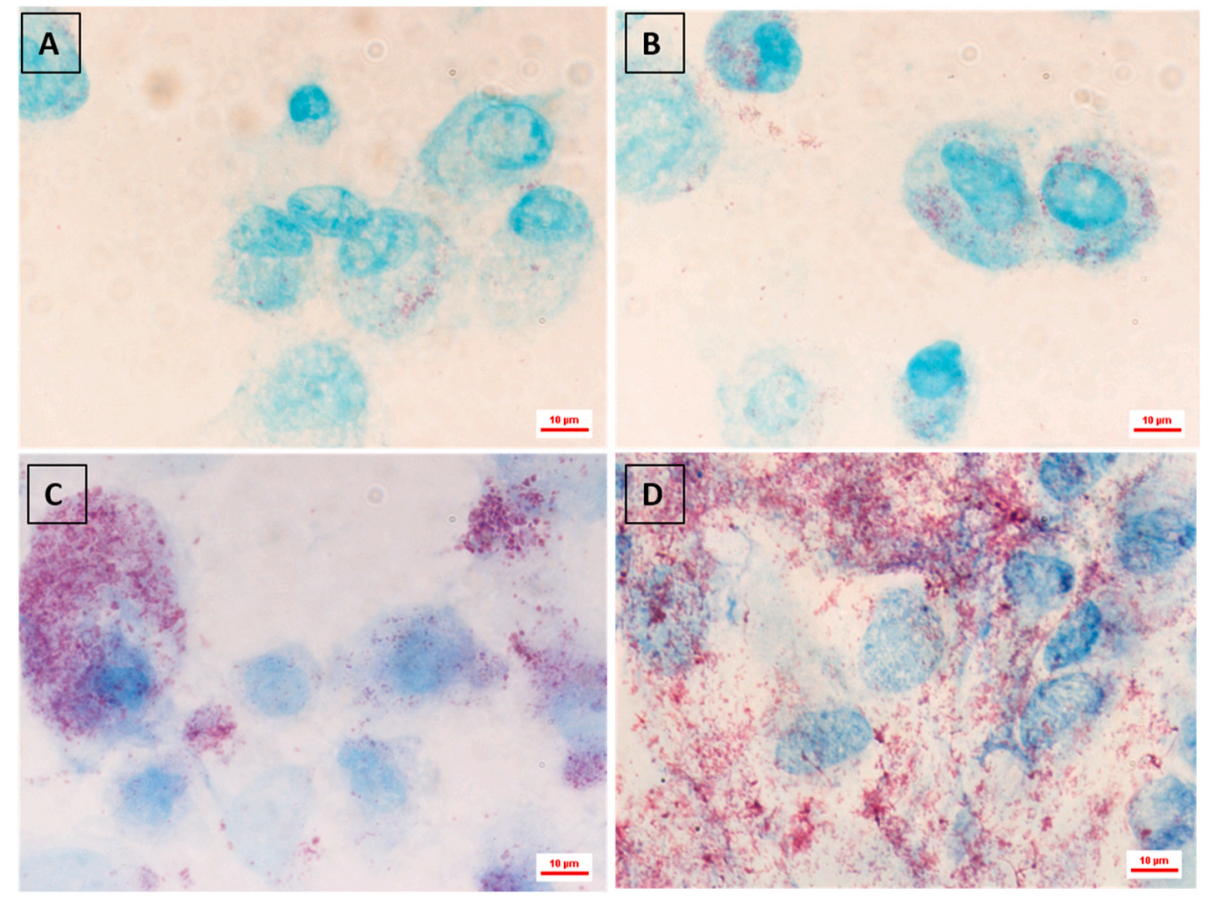

Fig. 2. Monitoring DPSCs infection by Bartonella quintana (Gimenez staining). (A): 12-h inoculation (B): 24-h inoculation (C): One-week inoculation (D): Fourweek inoculation. B. quintana inside DPSCs.
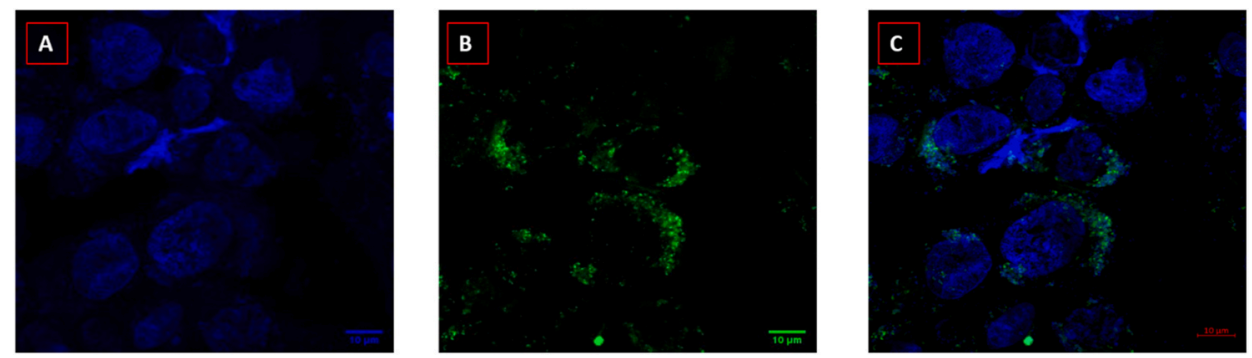

Fig. 3. Microscopic FISHing B. quintana into DPSCs. (A) DAPI filter (350 nm) visualizes cells in blue via the detection of their nuclei (B) FITC filter (488 nm) visualizes the 16S rRNA probe in green (C) merge of the two filters (DAPI and FITC). (For interpretation of the references to color in this figure legend, the reader is referred to the Web version of this article.)

suppression of MCP-1 does not affect replication of virus [38].

The role of MCP-1 remains unclear in B. quintana infection. Further investigations incorporating MCP-1 blocking antibodies may help defining the role of MCP-1 in the replication of B. quintana in DPSCs; but this experimental task was beyond the scope of the present study.
Nevertheless, this study is opening a new venue for DPSCs as sanctuary cells for the long-term survival of relapsing pathogens. 

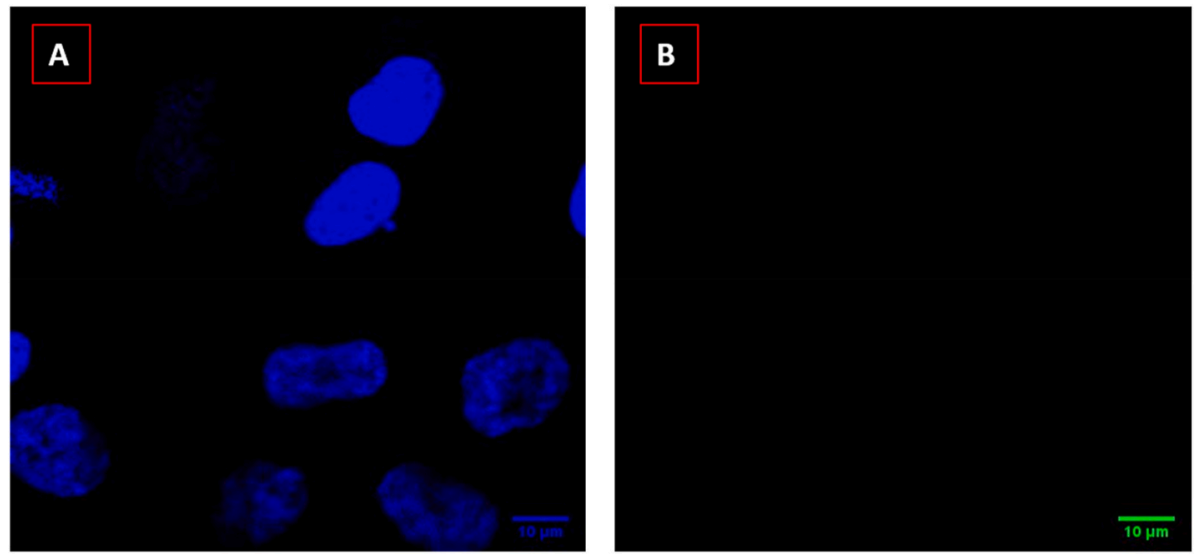

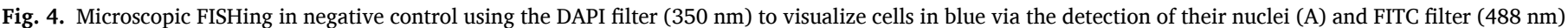
for the 16S rRNA probe (B). (For interpretation of the references to color in this figure legend, the reader is referred to the Web version of this article.)

Table 1

Quantitative determination of human MCP-1 concentrations (pg/mL in cell culture supernatants by ELISA.

\begin{tabular}{lll}
\hline Supernatants & & Concentration MCP-1 (pg/mL) \\
\hline 4th week & iDPSCs & 19867.85 \\
& DPSCs & 5250 \\
3rd week & iDPSCs & 12600 \\
\multirow{3}{*}{ First passage to a week } & DPSCs & 5153.58 \\
& iDPSCs & 11175 \\
& DPSCs & 4800 \\
\hline
\end{tabular}

iDPSC: $B$. quintana-infected DPSCs.

\section{CRediT authorship contribution statement}

Hamadou Oumarou Hama: performed the experiments, prepared figures, designed the experiments, conceived the experiments, Formal analysis, Data curation, analysed the data, Writing - original draft, wrote the manuscript. Attoumani Hamada: performed the experiments, prepared figures, designed the experiments, conceived the experiments, Formal analysis, Data curation, analysed the data, Writing - original draft, wrote the manuscript. Gérard Aboudharam: designed the experiments, conceived the experiments, Formal analysis, Data curation, analysed the data, Writing - original draft, wrote the manuscript. Éric Ghigo: designed the experiments, conceived the experiments, Formal analysis, Data curation, analysed the data, Writing - original draft, wrote the manuscript. Michel Drancourt: designed the experiments, conceived the experiments, Formal analysis, Data curation, analysed the data, Writing - original draft, wrote the manuscript.

\section{Declaration of competing interest}

The authors have no conflicts of interest to declare. The funding sources had no role in the study design, data collection and analysis, decision to publish, or manuscript preparation.

\section{Acknowledgements}

This work was supported by the French Government under the « Investissements d'avenir » (Investments for the Future) program managed by the Agence Nationale de la Recherche (ANR, fr: National Agency for Research), (reference: Méditerranée Infection 10-IAHU-03). This work was supported by Région Provence Alpes Côte d'Azur and European funding FEDER IHUBIOTK.

\section{Appendix A. Supplementary data}

Supplementary data to this article can be found online at https://doi. org/10.1016/j.micpath.2021.104797.

\section{References}

[1] M. Maurin, D. Raoult, Bartonella (Rochalimaea) quintana infections, Clin. Microbiol. Rev. 9 (1996) 273-292.

[2] W. Byam, Red Cross, U.S, American National Red Cross, Medical Research Committee, Committee on Trench Fever, Trench Fever; a Louse-Borne Disease, Frowde, London, 1919.

[3] P.-E. Fournier, H. Lelievre, S.J. Eykyn, J -L Mainardi, T.J. Marrie, F. Bruneel, C. Roure, J. Nash, D. Clave, E. James, C. Benoit-Lemercier, L. Deforges, H. TissotDupont, D. Raoult, Epidemiologic and clinical characteristics of Bartonella quintana and Bartonella henselae endocarditis: a study of 48 patients, Medicine (Baltim.) 80 (2001) 245-251.

[4] D. Raoult, P.E. Fournier, M. Drancourt, T.J. Marrie, J. Etienne, J. Cosserat, P. Cacoub, Y. Poinsignon, P. Leclercq, A.M. Sefton, Diagnosis of 22 new cases of Bartonella endocarditis, Ann. Intern. Med. 125 (1996) 646-652, https://doi.org/ 10.7326/0003-4819-125-8-199610150-00004.

[5] M. Drancourt, J.L. Mainardi, P. Brouqui, F. Vandenesch, A. Carta, F. Lehnert, J. Etienne, F. Goldstein, J. Acar, D. Raoult, Bartonella (rochalimaea) quintana endocarditis in three homeless men, N. Engl. J. Med. 332 (1995) 419-423, https:// doi.org/10.1056/NEJM199502163320702.

[6] M. Drancourt, R. Birtles, D. Raoult, G. Chaumentin, F. Vandenesch, J. Etienne, New serotype of Bartonella henselae in endocarditis and cat-scratch disease, Lancet 347 (1996) 441-443, https://doi.org/10.1016/S0140-6736(96)90012-4.

[7] J.E. Koehler, M.A. Sanchez, C.S. Garrido, M.J. Whitfeld, F.M. Chen, T.G. Berger, M. C. Rodriguez-Barradas, P.E. LeBoit, J.W. Tappero, Molecular epidemiology of Bartonella infections in patients with bacillary angiomatosis-peliosis, N. Engl. J. Med. 337 (1997) 1876-1883, https://doi.org/10.1056/NEJM199712253372603.

[8] S. Badiaga, P. Brouqui, Human louse-transmitted infectious diseases, Clin. Microbiol. Infect. 18 (2012) 332-337, https://doi.org/10.1111/j.14690691.2012.03778.x.

[9] B.B. Chomel, R.W. Kasten, K. Floyd-Hawkins, B. Chi, K. Yamamoto, J. RobertsWilson, A.N. Gurfield, R.C. Abbott, N.C. Pedersen, J.E. Koehler, Experimental transmission of Bartonella henselae by the cat flea, J. Clin. Microbiol. 34 (1996) 1952-1956.

[10] L. G. Rubin 181 - other gram-negative coccobacilli. In Principles and Practice of Pediatric Infectious Diseases, fourth ed. (ed. Long, S. S.) 939-941.e1 S.S.

[11] G. Greub, D. Raoult, Bartonella: new explanations for old diseases, J. Med. Microbiol. 51 (2002) 915-923, https://doi.org/10.1099/0022-1317-51-11-915.

[12] M. Mosepele, D. Mazo, J. Cohn, Bartonella infection in immunocompromised hosts: immunology of vascular infection and vasoproliferation, Clin. Dev. Immunol. (2012), https://doi.org/10.1155/2012/612809, 2012.

[13] G.L. Castoldi, L. del Senno, Erythrocytes, in: P.J. Delves (Ed.), Encyclopedia of Immunology, second ed., 1998, pp. 833-841.

[14] K. Kliche, P. Jeggle, H. Pavenstädt, H. Oberleithner, Role of cellular mechanics in the function and life span of vascular endothelium, Pflueg. Arch. Eur. J. Physiol. 462 (2011) 209-217, https://doi.org/10.1007/s00424-011-0929-2.

[15] M.A. Maxim, O. Soritau, M. Baciut, S. Bran, G. Baciut, The role of dental stem cells in regeneration, Med, Pharm. Represent. 88 (2015) 479-482, https://doi.org/ 10.15386/cjmed-475.

[16] T.N. Tran, C.L. Forestier, M. Drancourt, D. Raoult, G. Aboudharam, Brief communication: Co-detection of Bartonella quintana and Yersinia pestis in an 11th-15th burial site in Bondy, France, Am. J. Phys. Anthropol. 145 (2011) 489-494, https://doi.org/10.1002/ajpa.21510. 
[17] T. Nguyen-Hieu, G. Aboudharam, M. Signoli, C. Rigeade, M. Drancourt, D. Raoult, Evidence of a louse-borne outbreak involving typhus in douai, 1710-1712 during the war of Spanish succession, PloS One 5 (2010), e15405, https://doi.org/ 10.1371/journal.pone.0015405.

[18] M. Drancourt, L. Tran-Hung, J. Courtin, H. de Lumley, D. Raoult, Bartonella quintana in a 4000-year-old human tooth, J. Infect. Dis. 191 (2005) 607-611, https://doi.org/10.1086/427041.

[19] G. Aboudharam, P.-E. Fournier, M. Drancourt, D. Raoult, C. Foucault, P. Brouqui, Molecular detection of Bartonella quintana DNA in the dental pulp of a homeless patient, Eur. J. Clin. Microbiol. Infect. Dis. (2004), https://doi.org/10.1007/ s10096-004-1244-z.

[20] M. Dominici, K. Le Blanc, I. Mueller, I. Slaper-Cortenbach, F.C. Marini, D.S. Krause R.J. Deans, A. Keating, D.J. Prockop, E.M. Horwitz, Minimal criteria for defining multipotent mesenchymal stromal cells. The International Society for Cellular Therapy position statement, Cytotherapy 8 (2006) 315-317, https://doi.org/ $10.1080 / 14653240600855905$.

[21] S. Gronthos, M. Mankani, J. Brahim, P.G. Robey, S. Shi, Postnatal human dental pulp stem cells (DPSCs) in vitro and in vivo, Proc. Natl. Acad. Sci. U. S. A 97 (2000) 13625-13630.

[22] M.H. Allouba, A.M. ElGuindy, N. Krishnamoorthy, M.H. Yacoub, Y.E. Aguib, NaNog: a pluripotency homeobox (master) molecule, Glob. Cardiol. Sci. Pract. 2015 (2015), https://doi.org/10.5339/gcsp.2015.36.

[23] R. d'Aquino, G. Papaccio, G. Laino, A. Graziano, Dental pulp stem cells: a promising tool for bone regeneration, Stem Cell Rev. 4 (2008) 21-26, https://doi. org/10.1007/s12015-008-9013-5.

[24] P.-Y. Collart-Dutilleul, F. Chaubron, J. De Vos, F.J. Cuisinier, Allogenic banking of dental pulp stem cells for innovative therapeutics, World J. Stem Cell. 7 (2015) 1010-1021, https://doi.org/10.4252/wjsc.v7.i7.1010.

[25] Y. Zhao, L. Wang, Y. Jin, S. Shi, Fas ligand regulates the immunomodulatory properties of dental pulp stem cells, J. Dent. Res. 91 (2012) 948-954, https://doi org/10.1177/0022034512458690.

[26] H. Attoumani, M. Drancourt, E. Ghigo, Immune properties of human dental pulp stem cells and interactions with the immune system, ann, Stem Cell Res. Ther. 2 (2018).

[27] P. Bindal, T.S. Ramasamy, N.H.A. Kasim, N. Gnanasegaran, W.L. Chai, Immune responses of human dental pulp stem cells in lipopolysaccharide-induced microenvironment: immune responses by dental pulp stem cells, Cell Biol. Int. 42 (2018) 832-840, https://doi.org/10.1002/cbin.10938.

[28] P. Seng, M. Drancourt, F. Gouriet, B. La Scola, P.-E. Fournier, J.M. Rolain, D. Raoult, Ongoing revolution in bacteriology: routine identification of bacteria by matrix-assisted laser desorption ionization time-of-flight mass spectrometry, Clin. Infect. Dis. 49 (2009) 543-551, https://doi.org/10.1086/600885.

[29] V. Samyuktha, P. Kumar, B. Nagesh, K. Ranganathan, T. Jayaprakash, V. Sayesh, Cytotoxicity evaluation of root repair materials in human-cultured periodontal ligament fibroblasts, J. Conserv. Dent. JCD. 17 (2014) 467-470, https://doi.org/ 10.4103/0972-0707.139844.

[30] A. Loukil, P. Kirtania, M. Bedotto, M. Drancourt, FISHing Mycobacterium tuberculosis complex by use of a rpoB DNA probe bait, J. Clin. Microbiol. 56 (2018), https://doi.org/10.1128/JCM.00568-18.

[31] D. Raoult, BartoneUa Qub Tana Invades and Multiplies within Endothelial Cells in Vitro and in Vivo and Forms Intracellular Blebs, (n.d.) 13

[32] S.C. Eicher, C. Dehio, Bartonella entry mechanisms into mammalian host cells, Cell Microbiol. 14 (2012) 1166-1173, https://doi.org/10.1111/j.14625822.2012.01806.x

[33] P. Zhang, B.B. Chomel, M.K. Schau, J.S. Goo, S. Droz, K.L. Kelminson, S.S. George, N.W. Lerche, J.E. Koehler, A family of variably expressed outer-membrane proteins (Vomp) mediates adhesion and autoaggregation in Bartonella quintana, Proc. Natl. Acad. Sci. U. S. A 101 (2004) 13630-13635, https://doi.org/10.1073/ pnas.0405284101.

[34] C. Foucault, P. Brouqui, D. Raoult, Bartonella quintana characteristics and clinical management, emerg, Inf. Disp. 12 (2006) 217-223, https://doi.org/10.3201/ eid1202.050874.

[35] N.E.-M.B. Ahmed, M. Murakami, Y. Hirose, M. Nakashima, Therapeutic potential of dental pulp stem cell secretome for alzheimer's disease treatment: an in vitro study, Stem Cell. Int. (2016), e8102478, https://doi.org/10.1155/2016/8102478, 2016 .

[36] O. Andrukhov, J.S.-A. Hong, O. Andrukhova, A. Blufstein, A. Moritz, X. RauschFan, Response of human periodontal ligament stem cells to IFN- $\gamma$ and TLR-agonists, Sci. Rep. 7 (2017), https://doi.org/10.1038/s41598-017-12480-7.

[37] J. Srankova, J. Veteskova, M. Marusakova, L. Pivackova, G. Doka, P. Krenek, J. Klimas, Pegfilgrastim and linagliptin potentiate chemoattraction of Ccr2 and Cd44 stem cells accompanied by alterations of cardiac Hgf, Igf- 1 and Mcp-1 in daunorubicin cardiomyopathy, J. Pharm. Pharmacol. 71 (2019) 1440-1450, https://doi.org/10.1111/jphp.13133.

[38] M. Ruiz Silva, H. van der Ende-Metselaar, H.L. Mulder, J.M. Smit, I.A. RodenhuisZybert, Mechanism and role of MCP-1 upregulation upon chikungunya virus infection in human peripheral blood mononuclear cells, Sci. Rep. 6 (2016) 32288, https://doi.org/10.1038/srep32288. 